\title{
Defective Activation of the Third Component of Complement in the Sera of Newborn Infants
}

\author{
JERRY A. WINKELSTEIN, LAWRENCE E. KURLANDSKY, AND ANDREA J. SWIFT
}

The Howard Hughes Medical Institute Laboratory. Departments of Pediatrics and Microbiology. The Johns Hopkins University School of Medicine, Baltimore, Maryland, USA

\begin{abstract}
Summary
The activation of the terminal complement components, C3-9, plays an important role in the host's defense against infection. In the present study, the ability of bacteria to activate the third component of complement (C3) in newborn serum was examined.

$A$ variety of bacteria were incubated in test sera at $37^{\circ} \mathrm{C}$ for 30 min and the percent of available $C 3$ that was activated was measured. Using one strain of Escherchia coli (\#3), 32\% (mean) of the available $C 3$ was activated in sera from 18 newborns, as compared to $85 \%$ in sera from their mothers and $79 \%$ in sera from 13 normal adults $(P<0.005)$. In contrast, using another strain of $E$. coli (N70), the percent of $\mathrm{C} 3$ activated in newborn sera (83\%) was the same as in sera from their mothers $(81 \%)$ or in sera from normal adults (73\%). The defective activation of $\mathrm{C} 3$ in newborn sera by $E$. coli was not related to the presence of the K1 antigen. Newborn sera were also challenged with other bacterial species and the activation of $\mathrm{C} 3$ was deficient when tested with klebsiellae, but not with staphylococci or streptococci. The defect in newborn sera appeared to be due to a deficiency of a serum factor rather than to the presence of an inhibitor.
\end{abstract}

\section{Speculation}

The defective activation of $\mathrm{C3}-9$ in newborn sera by some bacteria may be, in part, responsible for the neonate's increased susceptibility to infection.

The terminal complement components (C3-9) play an important role in the host's defense against bacterial infections (5). However, in order to subserve their protective functions, C3-9 must first be activated to produce biologically active products. Activation of C3-9 by either the classical or the alternative pathway leads to the generation of chemotactic, opsonic, anaphylatoxic, and bactericidal activities.

Newborn infants are unusually susceptible to frequent and severe bacterial infections. A number of defects in host defense have been described in these infants, each of which could contribute to their increased susceptibility to infection (9). Among these. deficiencies in both serum chemotactic and opsonic activity have been identified in newborns $(2,4,7,8,12)$. Because these two serum activities are, at least in part, dependent on the activation of C3-9, the previously mentioned observations suggest that the activation of the terminal complement components might be defective in newborn sera.

Accordingly, in the following experiments, the ability of a variety of pathogenic bacteria to activate $\mathrm{C} 3$ in newborn sera was studied.

\section{MATERIALS AND METHODS}

\section{SERA}

Sera were obtained from the cord blood of 18 normal full term neonates at the time of their birth and from their mothers within
$12 \mathrm{hr}$ of delivery. Sera were also obtained from 13 normal adult males and females. Informed consent was obtained. Each sample was divided into small aliquots, frozen, and stored at $-70^{\circ} \mathrm{C}$.

\section{BUFFERS}

Veronal buffered saline, $\mathrm{pH} 7.4$, ionic strength 0.147 , with 0.15 $\mathrm{mM} \mathrm{Ca}^{++}, 1 \mathrm{mM} \mathrm{Mg}^{++}$, and $0.1 \%$ gelatin $\left(\mathrm{GVB}^{++}\right)$was prepared according to the method of $\mathrm{Kabat}$ and Mayer (6). Veronal

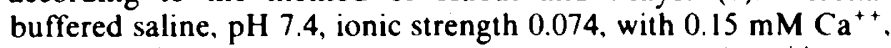
$1 \mathrm{mM} \mathrm{Mg}{ }^{++}, 0.1 \%$ gelatin, and $2.5 \%$ dextrose $\left(\mathrm{DGVB}^{++}\right)$was prepared according to the method of Shin and Mayer (11).

\section{BACTERIA}

The strains of Staphylococcus aureus, Klebsiella pneumoniae and group B $\beta$ hemolytic streptococci were isolated from the blood of infected neonates at the Johns Hopkins Hospital. The strains of $E$. coli were isolated from the blood or cerebrospinal fluid of infected neonates and were kindly supplied by Dr. John Robbins. the Bureau of Biologics, Food and Drug Administration. Bethesda, MD. They were tested for the presence of the $\mathrm{KI}$ antigen by their reaction with cross reacting antiserum to type $B$ meningococcus on solid media (10). The bacteria were grown in Trypticase Soy broth at $37^{\circ} \mathrm{C}$ for $18 \mathrm{hr}$, washed three times in $\mathrm{GVB}^{++}$, and suspended to the desired concentration in $\mathrm{GVB}^{++}$.

\section{C3 ACTIVATION}

The ability of bacteria to activate $\mathrm{C} 3$ in whole serum was tested as previously described (13). The appropriate organism was suspended to the desired concentration in test serum that had been diluted $1 / 10$ in $\mathrm{GVB}^{++}$, and the mixture incubated at $37^{\circ} \mathrm{C}$. After $30 \mathrm{~min}$, a sample was taken, diluted immediately in ice-cold $\mathrm{DGVB}^{++}$and the titer of functionally active $\mathrm{C} 3$ determined using a hemolytic assay (11). The amount of $\mathrm{C} 3$ consumed in each test sample was expressed as a percent of that amount of $\mathrm{C} 3$ remaining in a control sample of the test serum incubated with buffer alone.

\section{RESULTS}

ACTIVATION OF C 3 IN NEWBORN SERA BY VARIOUS STRAINS OF $E$.
COLII

E. coli, strain \#3 $(01: \mathrm{K} 1: \mathrm{H}-)$, were incubated at a concentration of $6 \times 10^{8} / \mathrm{ml}$ in the sera from newborn infants, their mothers, or normal adults and the consumption of $\mathrm{C} 3$ determined. As can be seen in Figure 1, when newborn sera were challenged with this strain of $E$. coli, there was significantly less consumption of the available $\mathrm{C} 3$ than when sera from either their mothers or normal adults were challenged $(P<0.005$ using the Student's $t$ test).

In contrast, when the same sera were challenged with a different strain of $E$. coli, strain N70 (023:K22:HI5), approximately the same percentage of the available $\mathrm{C} 3$ was consumed in the newborn sera as in the sera from their mothers or normal adults (Fig. 2).

The previous two series of experiments suggested that the defective activation of $\mathrm{C} 3$ in newborn sera by one strain of $E$. coli 


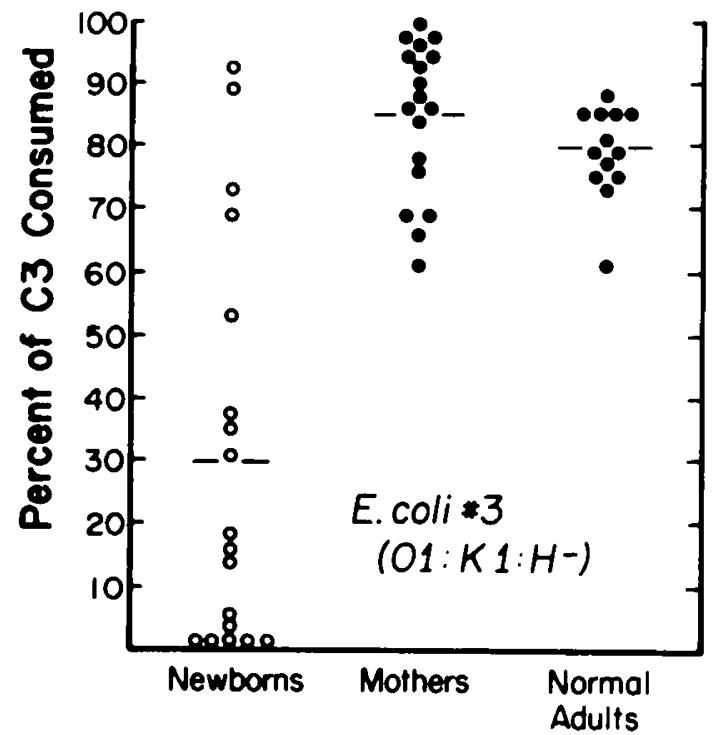

Fig. 1. The activation of $\mathrm{C} 3$ in a variety of sera by $E$. coli, \#3. The mean for each group is represented by the horizontal line.

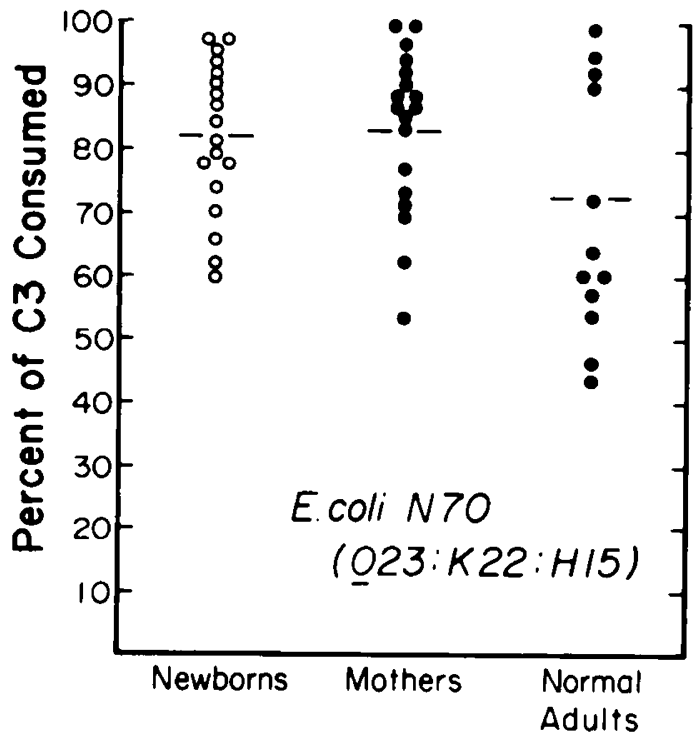

Fig. 2. The activation of $\mathrm{C} 3$ in a variety of sera by $E$. coli. N70. The mean for each group is represented by the horizontal line.

( $\mathrm{K}$ I positive), but not the other ( $\mathrm{K} I$ negative), might be related to the presence of the $\mathrm{KI}$ antigen. In order to examine that possibility. the serum from a single neonate and its mother were challenged with different strains of $K I$ positive and $K I$ negative $E$. coli over a wide range of bacterial concentrations. As can be seen in Figure 3. two of the Kl positive strains of $E$. coli gave activation of $\mathrm{C} 3$ in neonatal serum comparable to that in maternal serum, whereas two other $K I$ positive strains gave significantly less activation of $\mathrm{C} 3$ in the neonatal serum than in the maternal serum. As can be seen in Figure 4, two of the $\mathrm{Kl}$ negative strains of $E$. coligave activation of $C 3$ in the newborn serum comparable to that in the maternal serum, whereas two other $K I$ negative strains gave significantly less consumption of $\mathrm{C} 3$ in neonatal serum than in maternal serum. Comparable results were obtained when other neonatal-maternal serum pairs were tested in a similar manner. Thus, the defective activation of $\mathrm{C} 3$ in neonatal serum hy some strains of $E$. coli, but not others, does not appear to be solely related to the presence of the $\mathrm{KI}$ antigen.

\section{ACTIVATION OF ( 3 IN NEWBORN SERA BY OTHER BACTERIA}

The following experiments were performed in order to determine if the activation of $\mathrm{C} 3$ in neonatal sera was defective when tested with other species of bacteria. When newborn sera were challenged with $6 \times 10^{8} \mathrm{klebsiellae} / \mathrm{ml}$, there was significantly less consumption of $\mathrm{C} 3$ than when maternal sera were challenged $(P$ $<0.01$ ) (Fig. 5). In contrast, when the same neonatal sera were challenged with either group B streptococci or staphylococci at a concentration of $6 \times 10^{8} / \mathrm{ml}$, the percent of available $\mathrm{C} 3$ consumed was the same as that in the maternal sera (Fig. 5).

\section{EFFECT OF NEWBORN SERUM ON THE CONSUMPTION OF C 3 IN MATERNAL SERA}

The following experiments were performed in order to determine if the defective activation of $\mathrm{C} 3$ in neonatal serum was due to the presence of an inhibitor or due to a deficiency of a serum factor or factors. As can be seen in Table 1, when three different neonatal sera were challenged with $E$. coli $\# 3$ there was little, if any, consumption of the available $\mathrm{C} 3$, whereas the challenge of the maternal sera resulted in marked consumption of the available $\mathrm{C} 3$ in each case. When mixtures of neonatal and maternal sera were challenged, there was also marked consumption of the available $\mathrm{C} 3$. Thus, the defective activation of $\mathrm{C} 3$ in neonatal sera seemed to be due to a deficiency of a serum factor or factors, rather than to the presence of an inhibitor.

\section{DISCUSSION}

Activation of the terminal complement components, C3-9, results in the production of serum opsonic, anaphylatoxic, chemotactic, and bactericidal activities, all of which may serve to protect the host in its defense against infection (5). At least two mechanisms exist by which bacteria may activate C3-9, the classical and the alternative pathway. Activation of the classical pathway by bacteria requires the participation of antibody. In contrast, although antibody is able to participate in the activation of the alternative pathway by bacteria (14) little, if any, antibody is actually required. Which of these two pathways an individual strain or species of bacteria uses to activate C3-9 probably depends on a number of different factors such as the presence or absence of antibody, the relative concentrations of classical and alternative

\section{K1 Positive E. coli}

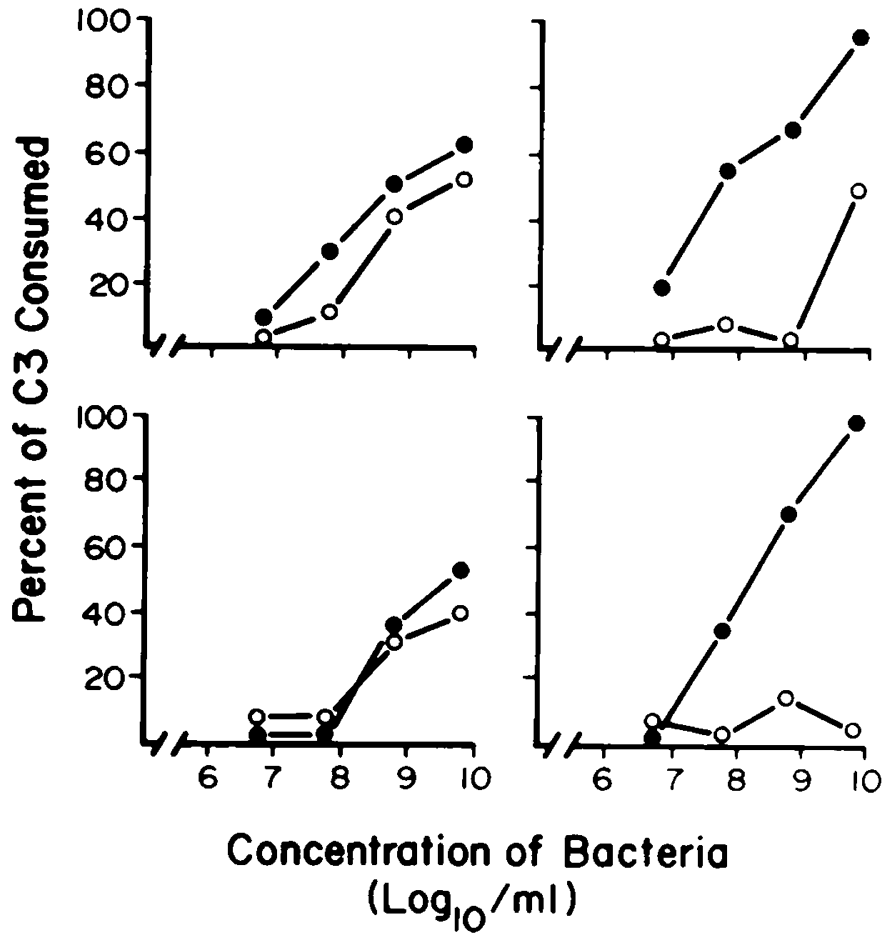

Fig. 3. The activation of $(3$ in the serum from a newborn infant (") and its mother (O) by four different strains of $\mathrm{K} /$ positive $E$. coli. 


\section{K1 Negative E. coli}

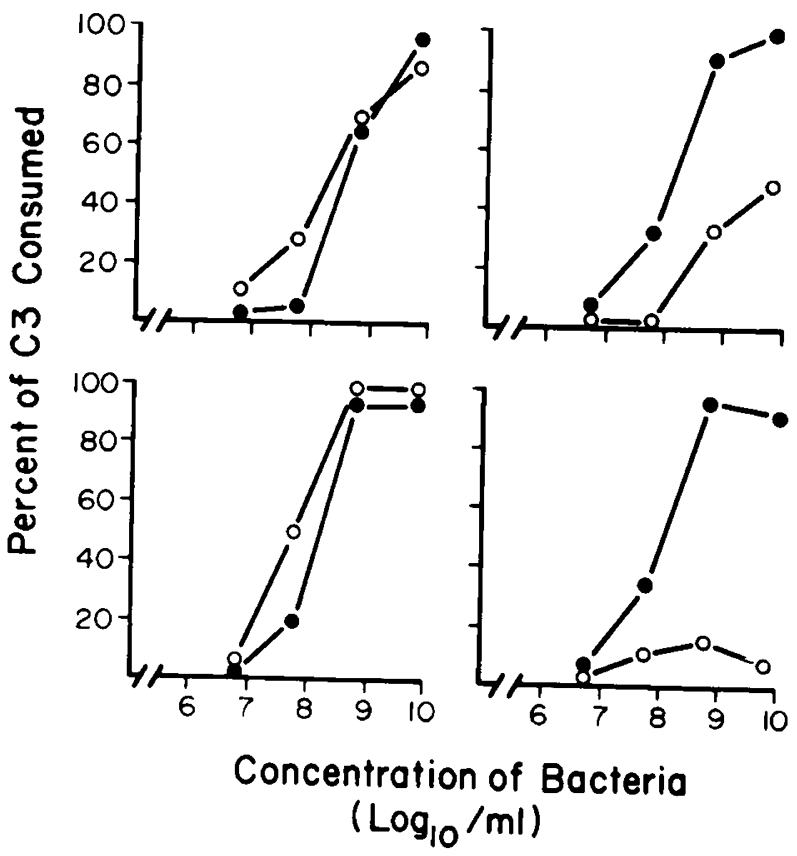

Fig. 4. The activation of $\mathrm{C} 3$ in serum from a newborn infant $(O)$ and its mother $(\Theta)$ by four different strains of $\mathrm{K} 1$ negative $E$. coli.

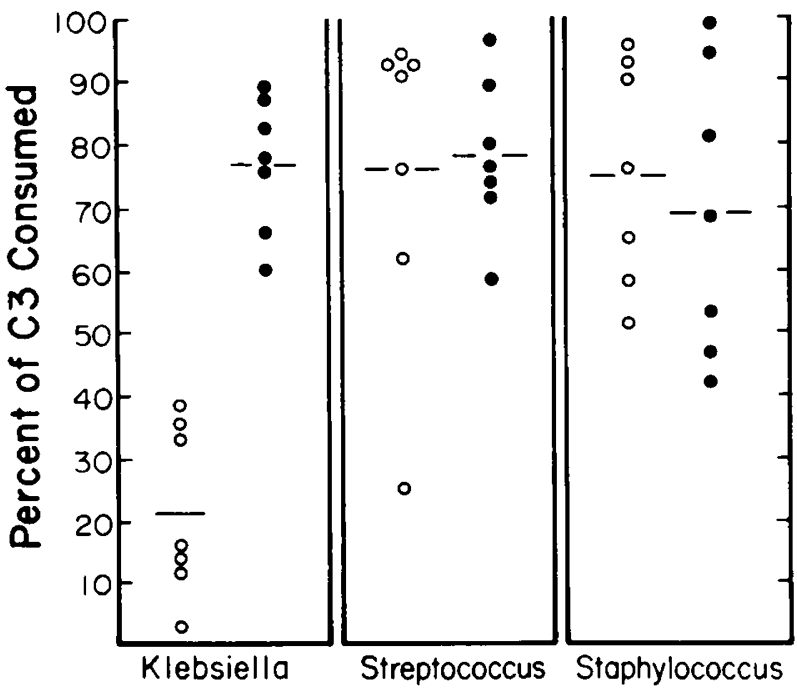

Fig. 5. The activation of $\mathrm{C} 3$ in sera from newborn infants $(O)$ and their mothers $(\theta)$ by a variety of bacterial species. The mean for each group is represented by the horizontal line.

Table 1. The effect of newborn serum on consumption of $C 3$ in maternal serum by $E$. Coli \#3

\begin{tabular}{lcccc}
\hline & \multicolumn{3}{c}{ Percent of C3 Consumed } \\
\cline { 2 - 5 } \multicolumn{1}{c}{ Sera } & Exp \#1 & Exp \#2 & Exp \#3 \\
\hline $10 \%$ newborn & 0 & 0 & 17 \\
$10 \%$ maternal & 100 & 87 & 82 \\
$10 \%$ newborn + 10\% maternal & 87 & 100 & 84 \\
\hline
\end{tabular}

pathway components and the intrinsic ability of the bacteria to activate the alternative pathway.

A number of studies have been performed on the complement system of newborns. Levels of the individual components of the classical complement system, C1-9, have been found to be significantly depressed in the cord blood of neonates (1). In addition, one of the components of the alternative pathway, factor $\mathrm{B}$, has been shown to be decreased in neonates $(3,12)$.

The present experiments were designed to study the ability of bacteria to activate $\mathrm{C} 3$ in newborn sera. The bacteria selected for use were chosen because they are common pathogens in the newborn period. The ability of these bacteria to activate $\mathrm{C} 3$ was studied because $\mathrm{C} 3$ itself plays an important role in the host's defense against infection (15), and also serves as part of the enzyme that activates C5-9 (5). No attempt was made in the present experiments to study the activation of $\mathrm{C} 3$ exclusively by either the classical or alternative pathway. Rather, the total amount of $\mathrm{C} 3$ activated by both pathways was measured in each serum sample because it more accurately reflects the situation as it occurs in vivo.

In the present study, the activation of $\mathrm{C} 3$ in newborn sera was found to be deficient when tested with two different gram-negative species, $E$. coli and klebsiella. In contrast, when these same sera were tested with two different gram-positive organisms, staphylococcus and group B streptococcus, the activation of $\mathrm{C} 3$ was normal. In addition, not all strains of $E$. coli were found to cause defective activation of $\mathrm{C} 3$ in newborn sera. The results, however, for a given species and strain of bacteria were consistent from infant to infant. The reason(s) why some bacteria cause defective activation of $\mathrm{C} 3$ in newborn sera and others do not is unknown. In the case of $E$. coli, the results of the present experiments suggest that the defective activation of $\mathrm{C} 3$ is not solely due to the presence of the $\mathrm{K} \mathrm{l}$ antigen.

The defect or defects in newborn sera responsible for the deficient activation of $\mathrm{C} 3$ are unknown. The results of the present study would suggest, however, that the defective activation of $\mathrm{C} 3$ is due to a deficiency of a serum factor or factors, rather than to the presence of an inhibitor. The defective activation of $\mathrm{C} 3$ by some bacteria, but not by others, may be related to a number of variables such as the relative integrity of the classical and alternative pathways in newborn sera, the absence of $\operatorname{IgM}$ in newborn sera, or the relative abilities of the different bacteria to activate each pathway. The fact that some bacterial species and strains are able to activate $\mathrm{C} 3$ normally in newborn sera implies that at least one activation mechanism is intact in newborn sera.

The results of the present study demonstrate that the activation of $\mathrm{C} 3$ in neonatal serum is defective when tested with some, but not all, bacteria. Because the activation of $\mathrm{C} 3-9$ plays an important role in the host's defense against infection, it is possible that the defective activation of $\mathrm{C} 3$ in newborn serum contributes to the neonate's remarkable susceptibility to bacterial infection.

\section{REFERENCES AND NOTES}

I. Ballow, M., Fang, F., Good, R. A., and Day, N. K.: Developmental aspects of complement components in the newborn: the presence of complement components and $\mathrm{C} 3$ proactivator (Properdin Factor B) in human colostrum. Clin Exp. Immunol., 18: 257 (1974).

2. Dossett, J. H., Williams, R. C., and Quie, P. G.: Studies on interaction of bacteria, serum factors, and polymorphonuclear leukocytes in mothers and newborns. Pediatrics, 44: 49 (1969).

3. Feinstein, P. A., and Kaplan, S. R.: The alternative pathway of complement activation in the neonate. Pediatr. Res., 9: 802 (1975).

4. Forman, M. L., and Stiehm, E. R.: Impaired opsonic activity but normal phagocytosis in low birth weight infants. N. Engl. J. Med., 281: 926 (1969)

5. Johnston, R. B. Jr., and Stroud, R. M.: Complement and host defense against infection. J. Pediatr., 90: 169 (1977).

6. Kabat, E., and Mayer, M. M.: In: Kabat and Mayer's Experimental Immunochemistry, 2nd ed., Chap. 4 (Charles C. Thomas, Springfield, IL, 1967).

7. McCracken, G. H., and Eichenwald, H. F.: Leukocyte function and developmen of opsonic and complement activity in the neonate. Am. J. Dis. Child., 121: 120 (1971)

8. Miller, M. E. Chemotactic function in the human neonate: Humoral and cellular aspects. Pediatr. Res., 5: 487 (1971).

9. Miller, M. E.: Host defenses in the human neonate. Ped. Clin. North Am., 24: 413 (1977).

10. Sarf,, L. D., McCracken, G. H., Schiffer, M. S., Glode, M P., Robbins, J. B., Ørshov, I., and Ørshov, K.: Epidemiology of Escherichia coli $\mathrm{K} 1$ in healthy and diseased newborns. Lancet, $1: 1099$ (1975).

11. Shin, H. S., and Mayer, M. M.: The third component of the guinea pig complement system. II. Kinetic Study of the reaction of EAC4,2a with guinea pig C3. Biochemistry, 7: 2997 (1967).

12. Stossel, T. P., Alper, C. A., and Rosen, F. S.: Opsonic activity in the newborn role of properdin. Pediatrics, 52: 487 (1971). 
13. Winkelstein, J. A., Shin, H. S., and Wood, W. B. Jr.: Heat labile opsonins to pneumococcus. III. The participation of immunoglobin and of the alternative pathway of C3 activation. J. Immunol., 108: 1681 (1972).

14. Winkelstein, J. A., and Shin, H. S.: The interaction of pneumococci and the properdin pathway: the role of gamma-2 immunoglobulin. J. Immunol, 112: 1635 (1974).

15. Winkelstein, J. A., Smith, M. R., and Shin, H. S.: The role of $\mathrm{C} 3$ as an opsonin in vivo in the early stages of infection. Proc. Soc. Exptl. Biol. Med., 149: 395 (1975)

Copyright (C) 1979 International Pediatric Research Foundation, Inc. $0031-3948 / 79 / 1310-1093 \$ 02.00 / 0$
16. This research was supported, in part, by United States Public Health Service Grant AI-11637. Jerry A. Winkelstein is an Investigator of the Howard Hughes Medical Institute.

17. Requests for reprints should be addressed to: Jerry A. Winkelstein, M. D., Department of Pediatrics, The Johns Hopkins Hospital, $600 \mathrm{~N}$. Wolfe Street, Baltimore, MD 21205, USA.

18. Received for publication August 4, 1978

19. Accepted for publication October 24, 1978 